Published as: Otosoa, K.M., Derudder, B., Bassens, D., Devriendt, L. \& Witlox, F. (2011), Airline connectivity as a measure of the globalization of African cities. Applied Geography, vol. 31 (2), pp. 609-620.

\title{
AIRLINE CONNECTIVITY AS A MEASURE OF THE GLOBALIZATION OF AFRICAN CITIES
}

\author{
Kefa M. Otiso ${ }^{\mathrm{a}}$, Ben Derudder ${ }^{\mathrm{b}}$, David Bassens $^{\mathrm{b}}$, Lomme Devriendt $^{\mathrm{b}}$ \& Frank Witlox $^{\mathrm{b}}{ }^{*}$ \\ ${ }^{a}$ Bowling Green State University, Department of Geography, Bowling Green, OH 43403 \\ Email: kmotiso@bgsu.edu \\ ${ }^{\mathrm{b}}$ Ghent University, Department of Geography, Krijgslaan 281 (S8), 9000 Ghent, Belgium \\ Email: ben.derudder@ugent.be; david.bassens@ugent.be; lomme.devriendt@gmail.com; \\ frank.witlox@ugent.be \\ * Corresponding author.
}

\begin{abstract}
A city's transnational airline connections are one measure of its globalization since such links are integral to globalization. In this paper, we use airline networks to (i) map the position of African cities in the global transnational urban network, (ii) explore the inter-urban relationships of major African cities and, (iii) to contribute to the literature on the globalization of African cities. We find that whereas many African cities have poor airline interconnectivity among themselves as well as internationally, and are thus ranked low on global transnational urban networks, some cities such as Johannesburg, Cairo, Cape Town, Nairobi, Durban, and Casablanca have developed relatively good international air connectivity and are thus relatively well integrated into the global transnational urban network. In particular, South African cities, especially Johannesburg, have substantially increased their air connectivity and place in the global transnational urban network since the advent of majority rule in South Africa in 1994.
\end{abstract}

Keywords: globalization, world cities, African cities, African airlines, Johannesburg, Cairo, Cape Town, Nairobi, Durban, Casablanca

\section{Introduction}

The globalization of African cities can be analyzed in the context of four temporal phases (i.e., pre-colonial, colonial, national, and global) that not only exhibit distinct historical, economic, political, spatial, social, cultural and urban changes but also "reflect fundamental changes in the nature and extent of the global political economy and differential external linkages of the city" (Grant and Nijman 2002, p. 323). Many African cities experienced minimal globalization in the pre-colonial and national phases because they were either nonexistent or under the sway of anti-globalization nationalist forces. In the colonial era, many of the 
continent's cities globalized as colonial capitalism linked them to cities in their colonial mother countries such as the United Kingdom (UK). However, because of restricted surplus product owing to the generally small colonial economies as well as underdeveloped transport and communication facilities, the globalization of African cities in the colonial era was limited.

In the global phase, starting in the 1980s, many African cities started to globalize rapidly as their host nations liberalized their economies and adopted World Bank - International Monetary Fund (IMF) Structural Adjustment Policies (SAPs). Moreover, improved transport and communication connections with the outside world, coupled with economic difficulties in many African countries forced many of their nationals to relocate to other global destinations in search of better socioeconomic opportunities. These transnational émigrés, coupled with the heightened expansion of many global corporations into Africa and the continent's improved transport and communications with the outside world in the global era, have contributed to the rapid globalization of many African cities since the 1980s (Otiso and Owusu 2008). Nevertheless, the globalization of African cities in the recent past is far from uniform as emerging studies of globalizing African cities such as Accra, Nairobi, and Johannesburg have shown (Grant 2009, Otiso and Owusu 2008, Robinson 2006). In spite of these recent studies, however, the globalization of many African cities remains poorly understood because of the rather limited scholarly attention (with notable exceptions being Rakodi 1998, Van der Merwe 2004, Pirie 2010, and Grant 2009), largely because the continent is seen as being marginal to the global economy and, therefore, devoid of the so-called 'global cities' that are "the sites for the control and management of TNC [Transnational Corporation] operations, specialized business services to back these up, and nodes in the world banking and commercial system" (Rakodi 1998: 329-330) ${ }^{1}$. Even in the category of the so-called 'regional' or 'sub-global' cities, few African cities measure up, notably Johannesburg, Nairobi, Cairo, Cape Town and Lagos (Simon 1992: 83-94, Friedmann 1995, Rakodi 1998, Yousry, Abu-Zekry and Yousry 1998, Derudder et al. 2003, Van der Merwe 2004, Lemanski 2007).

The main objective of this paper, therefore, is to use airline networks to (i) map the position of African cities in the global transnational urban network, (ii) explore the inter-urban relationships of major African cities and, (iii) to thereby contribute to the globalization of African cities literature. We focus on the place of Africa in the global airline network because efficient global transport and communications are integral to globalization; they are the blood vessels of the global economy (Cidell 2006, Hummels 2007). Thus, the quality of African airline links with the rest of the world significantly impacts the globalization of African cities (Pedersen 2001). Indeed, the quality of such networks is itself a measure of a city's, country's or continent's level of globalization.

The remainder of this paper is organized as follows. First, we develop the rationale for analysing transnational urban connectivity through airline flows. Second, we look at a number of data problems in previous

\footnotetext{
${ }^{1}$ It is therefore no surprise that the benchmark volume of Armstrong and McGee (1985) on 'Third World urbanization' focuses on Asian and Latin American cities.
} 
researches, and discuss how our data source is able to circumvent some of these problems. Third, we present the actual empirical analysis and explore African urban connectivity in terms of direct and indirect airline connections and regional and extra-regional flows. Finally, we summarize our main findings and outline some avenues for future research.

To facilitate understanding of our central arguments, we offer a definition of certain key terms as used in this paper. The transnational urban network is the interconnected system of cities that extends beyond national borders within which the constituent cities are located. This system extends from the regional to the global scale i.e., the whole world. While transnational flows can be synonymous with international flows, the former term is used herein to refer to flows across the originating nation's boundaries while the latter term generically refers to flows between two or more nations or countries. In the context of air transport, transnational flows are a useful analytical concept because the origin, direction, and the amount of airline passenger flows matters greatly and an international boundary can significantly alter these variables. Additionally, many countries have no airlines or significant airline hubs of their own, and while some countries (e.g. South Africa) have good internal airline networks, others lack such well articulated systems and often have one dominant city that is well connected to the outside world e.g. Nairobi, Kenya. Moreover, in the airline industry, the number and intensity of flights to/from a hub, the origins and destinations of its flights, and the number of airlines and connections that serve it are all significantly influenced by the relative location and centrality (rank) of a given hub or node. Finally, global links are those that are worldwide in nature.

\section{The position of airline data within the research on transnational urban networks}

\subsection{Empirical research on transnational urban networks}

Through the 1990s one particular criticism of the literature on 'global cities' became commonplace: there was a severe empirical deficit on inter-city relations (e.g. Smith and Timberlake, 1995; Taylor, 1997, Beaverstock et al., 2000a,b). This major research bottleneck - more so given the intensity of worldwide airline interconnections and myriads of other linkages between key metropolises around the world - led Peter Taylor and some colleagues to start a global research network to address the lacuna of data and research in this area: the Globalization and World Cities research group (GaWC, www.lboro.ac.uk/gawc). One of the key problems in transnational urban research is that standard data sources for social science research are ill-suited for empirical analyses (Taylor 1997). Researchers normally rely on 'state-istics', which are usually gathered by a state agency for the particular needs of government policy rather than for social science research. Standard statistics therefore have an attributional bias instead of a relational bias (measurements of administrative areas rather than relations between administrative areas). Furthermore, they are limited to national territories. Where official statistics extend beyond a state's boundaries they still use countries as the basic units of analysis (e.g. trade data). Thus, there is no readily available data on transnational flows between cities on a global scale. This evidential crisis has, however, been bypassed in recent years in two ways (Derudder, 2006): 
(i) by analyzing worldwide corporate organization (e.g. Alderson \& Beckfeld, 2004) and (ii) by describing the infrastructure that has enabled organizations to go global (e.g. Graham, 1999).

The work of the GaWC group has been crucial in developing the 'corporate organization approach' that starts with the idea that firms pursuing global strategies are the prime agents in the formation of urban networks, even those involving airlines and information flows (Malecki and Hu, 2009). The GaWC researchers, who based their data collection on the global office location networks of major producer service firms in the fields of law, banking, insurance and advertising, anchored their work on transnational urban networks on the assumption that advanced producer service firms 'interlock' cities through their intra-firm transfers of information, knowledge, plans, directions, advice, etc. thereby creating a network of global service centres (Taylor, 2001, Taylor et al. 2002; for a similar methodological approach, see e.g. Alderson and Beckfield 2004).

The 'infrastructure approach', on the other hand, starts from the observation that advanced telecommunication and transportation infrastructures are tied to cities that structure the global economy. The emergence of the Internet in the mid-90s aggregated and transformed the complex ways in which information and capital could be transferred. The boundless possibilities of this medium and the global coverage of its infrastructure made cities increasingly dependent on Information and Communication Technologies (ICT) networks for their exchange of information through, for instance, virtual private networks and video conferencing (Malecki and $\mathrm{Hu}, 2009)$. In addition, important airline networks have arisen across the globe, especially between the major cities. These enabling (tele)communication and transportation networks are the foundation on which the connectivity of key cities is built. Thus, it is no surprise that their geographies have been used to invoke a spatial imagery of urban networks (see e.g. Derudder and Witlox 2005, Devriendt et al. 2008, Malecki and $\mathrm{Hu}, 2009)$. In this paper, we use the transnational connections of major African cities to further develop this air transport-based approach and to investigate the globalization of these cities.

\subsection{Airline networks and urban networks: opportunities and pitfalls}

Apart from the fact that airline data are (comparatively) easy to obtain, the usefulness of this data source is summarized by the fact that "because of its relatively rapid capacity to reply in terms of supply and demand, air traffic provides a pertinent indicator in the quest to evaluate the international character of [...] cities" (Cattan, 1995: 303). Smith and Timberlake (2001, 2002) and Keeling (1995) in their appraisal of the empirical usefulness/suitability of airline linkages in assessing the globalization of cities present five interrelated arguments in favor of these linkages:

1. global airline flows are one of the few indices available of transnational flows of interurban connectivity;

2. air networks and their associated infrastructure are the most visible manifestation of world city interaction; 
3. great demand still exists for face-to-face relationships, despite the global telecommunications revolution;

4. air transport is the preferred mode of inter-city movement for the transnational capitalist class, migrants, tourists, and high-value goods; and

5. airline links are an important component of a city's aspirations to world city status.

The use of airline data for measuring urban connectivity has, however, also been criticized in two main ways. First, these data do not necessarily make it easy to link flows to specific globalization processes occurring in/from/to cities (Derudder, 2006). As a result, researchers have been forced to consider other flows and measures, e.g., the global distribution of corporate headquarters or specialized service firms (e.g., Alderson and Beckfield 2004, Taylor et al. 2009) even though recent research has shown convincingly that this empirical focus has (re-)produced a Western bias in globalized urbanization research since the criteria used in the identification of the reputed 'global cities' are dominated by ethnocentric Anglo-American approaches (Robinson 2006, Lemanski 2007, Shatkin 2007, Bassens et al. 2010). Yet the supposed drawback of airline data - 'general' flow measures - can in this context be seen as an asset, as the measures reflect the aggregation of heterogeneous processes that lead to urban connectivity. Even in our case, the use of airline networks to assess Africa's global urban connectivity is desirable because such data are capable of assessing the relational capacity of cities beyond a subset of highly connected 'world African cities' such as Johannesburg, Cairo, Casablanca, Nairobi, and Cape Town. Besides, this approach recognizes the reality that all major cities operate at various scales, and although the importance of their respective functions may vary, it is doubtful that one can pin down a clear-cut border between a limited number of 'global cities', thoroughly influenced by and influencing globalization, and 'non-global cities' (Knox 1996). For instance, the international capacity of Durban and Windhoek may be limited when compared to Johannesburg or Cape Town, but this does not mean that these are by definition 'regional' or 'national' cities. In short, the use of airline data allows us to obtain general measures of transnational connectivity, even for cities that do not commonly feature on the map of global cities (cf. Robinson 2006).

Second, most standard airline data are ill-suited for analyses of transnational urban networks because they are structurally flawed (Derudder and Witlox 2005). Besides lacking information on the actual routes flown, these data are far from 'global' given their narrow international/regional focus. Thus, standard airline data, such as that from the Official Airline Guide (OAG), a provider of data on every scheduled passenger and cargo airline flight, contain information on the individual legs of a given trip rather than on the trip as a whole. As a result, if a passenger makes use of a hub, the route is collected twice in standard airline databases: one time for the origin-hub route and another time for the hub-destination route. For example, a passenger flying from Windhoek (Namibia) to London via Johannesburg will not be recorded as a single 'Windhoek - London' passenger, but will rather be separately recorded as a 'Windhoek - Johannesburg' and 'Johannesburg London' passenger. Not only does this obscure the importance of hub cities (as there should be a difference in interpretation between hub connectivity and origin/destination connectivity), it also makes air transport relations between secondary cities difficult to measure as these involve, by definition, an intermediate stop. 
Regarding the spatial coverage issue, none of the standard aviation data sources are truly global or worldwide in coverage. Hence, even airline data sources that would appear to be global, e.g. those from the International Civil Aviation Organization (ICAO) and the International Air Transport Association (IATA), only offer selective global coverage. Other data sources, e,g., the Association of European Airlines (AEA) have a distinct regional focus. Moreover, international airline data tend to capture inter-country (i.e., between countries) rather than trans-country (or across country) flows. Consequently, these data mask important national or intra-country (within country) connections such as those between the South African cities of Cape Town - Johannesburg. Furthermore, because secondary cities such as Durban, South Africa, often lack direct connections to non-African cities, it makes it virtually impossible to assess their 'international' linkages. Regional airline data, on the other hand, obviously focus on specific world regions which makes them unsuitable for any analysis of the flows within the global urban network. For these reasons, relying on standard data such as those from OAG, would seriously distort our analysis of African cities' global connectivity. For this reason, this paper is based on a 2001 (and to a limited extent 2009) dataset that overcomes most of the data problems associated with standard airline data.

\section{Standard Airline Data Problems and the Suitability of the Marketing Information Data Transfer (MIDT) dataset}

The MIDT database used in this study is able to overcome the most pressing problems commonly associated with the use of standard airline data because it contains information on airline bookings made through the socalled Global Distribution Systems (GDS), that is, electronic platforms used by travel agencies to manage airline bookings, hotel reservations, and car rentals worldwide. Well-known examples of GDS are Galileo, Apollo, Sabre, Worldspan, Amadeus, Topas, Infini and Abaccus. For every booking made through a GDS, the MIDT-database records information on airline codes, flight numbers, airport codes of the board on/off cities, switching points (if any), booking date, departure date, agency name, cancellation indicators, and so on. Through the cooperation of a specific airline, we obtained these data for the January-August 2001 period which includes over 500 million passenger movements throughout the world ${ }^{2}$. While we later use a smaller 2009 dataset to update certain aspects of the study, the bulk of the paper is based on the 2001 dataset.

It is important to note from the outset that there is an important disadvantage associated with the use of GDSoriented databases. Due to the GDS-origins of the MIDT data, bookings made directly with an airline are often excluded from the MIDT dataset. Often airlines choose this direct booking option to avoid the fees charged by travel agencies. Direct bookings via the Internet are estimated to cost an airline US $\$ 1$, while bookings through travel agents cost an estimated US\$10 (Goetzl 2000). Low-cost carriers such as Southwest, EasyJet, Virgin, and Ryanair therefore specifically restrict themselves to direct sales to avoid the extra costs associated with the use of GDS and operate on regional scales. It is estimated that in 1999 about $20 \%$ of all

\footnotetext{
${ }^{2}$ Though this dataset is a decade old, it is acceptable for our present purpose. Moreover, such data are difficult to find.
} 
airline trips were booked directly with airlines (Miller 1999). Thus, although our data source might provide a biased picture of airline transport, the GDS level of coverage is still impressive. Besides, it is doubtful that the spatiality of the reservations made by direct bookings differs fundamentally from those of reservations made through GDS. This is more so true of our study area (Africa) since low-cost networks were not widely developed in 2001 when our dataset was obtained (Macario 2008). Additionally, whereas major African airlines have grown since then, low-cost carriers are still few and small. Also, recent research by Alderson et al. (2010) and Derudder et al. (2010) has indicated that inter-city relations in general, and African inter-city relations in particular, are relatively stable. Moreover, there have been promising efforts to combine supply (OAG) and demand (MIDT) data, which have been able to calculate the relationship between both datasets in terms of load factors (Devriendt et al., 2009). For instance, where OAG lists '50,000' between city A and city B, the MIDT data might show that $20 \%$ of these incoming passengers use city B as a hub (see Derudder et al., 2007). For short term purposes, it would therefore be possible to draw on MIDT data to correct existing OAG data, in this case generating a corrected number of passengers of ' 40,000 ' between city A and city B. Hence, for the purposes of this study, the 2001 MIDT database is still valuable.

For the purposes of this study, we transformed the initial MIDT-database in two ways. First, we reduced the size of the database by extracting only information pertaining to African cities i.e., only connections from/to/through African cities were preserved. The second transformation entailed the recoding and aggregation of airport codes into city codes. For Johannesburg, for instance, all connections of Randgermiston Airport (IATA code: QRA) were complemented with those of Johannesburg International Airport (JNB), thus obtaining a single, aggregated measure for the city as a whole ${ }^{3}$. These transformations resulted in a total of 381 African cities that are included in this analysis. Table 1 reveals the key possibilities of our dataset. The table summarizes the actual connections on the Cape Town - London route during the period under investigation. Since intermediate switching points are recorded as extra information, it remains possible to contrast direct and indirect inter-city relations and to measure the city's hub function. Most passengers travel directly between Cape Town and London. However, besides this direct connection, Johannesburg and Amsterdam are important hubs for the London-Cape Town link.

Table1: Direct and indirect connections for the connection Cape Town - London (> 100 origin-destination passengers).

\begin{tabular}{|l|l|l|l|}
\hline Connection & Hub1 & Hub2 & Total Pax \\
\hline Cape Town - London & & & 196,269 \\
\hline Cape Town - London & Johannesburg & & 8,292 \\
\hline Cape Town - London & Amsterdam & & 5,965 \\
\hline Cape Town - London & Frankfurt & & 4,766 \\
\hline
\end{tabular}

\footnotetext{
${ }^{3}$ In reality, airport codes do not exclusively refer to airports, but may also encompass train and bus stations.
} 


\begin{tabular}{|l|l|l|l|}
\hline Cape Town - London & Istanbul & & 2,469 \\
\hline Cape Town - London & Windhoek & & 1,268 \\
\hline Cape Town - London & Johannesburg & Zurich & 798 \\
\hline Cape Town - London & Johannesburg & Vienna & 457 \\
\hline Cape Town - London & Johannesburg & Paris & 305 \\
\hline Cape Town - London & Johannesburg & Brussels & 286 \\
\hline Cape Town - London & Johannesburg & Athens & 104 \\
\hline
\end{tabular}

Source: Authors

\section{Empirical analysis: the position of African cities in transnational airline networks}

\section{4a. Cities as origin/destination $(O / D)$ nodes: connectivity and spatiality}

Since our data cover genuine O/D-flows rather than offered capacities, and as MIDT is a truly global database, we are able to examine the transnational inter-urban relationships of African cities in terms of total O/D passenger volumes. Moreover, we examine the spatial distribution of these OD connections wherein we first explore the division between African and non-African links for a large number of African cities. Thereafter, we present the spatial connectivity of five major African cities in more detail (i.e. Durban, Johannesburg, Cairo, Casablanca, Nairobi, and Cape Town).

Figure 1 presents the total volume of OD passengers for the 25 most important African cities, and unravels the spatial patterns of these flows by distinguishing the African and non-African inter-city flows. Our interest in this model particularly focuses on the relative position of a city in comparison to the number of African and non-African passengers. As the figure shows, Johannesburg, Cairo, Cape Town, Durban, Casablanca, Nairobi, and Tunis are the most dominant African cities in terms of air traffic: they had more than one million passengers for their OD connections in the period under investigation. Next to these top cities in terms of OD connectivity, are the important economic and financial cities of Port Louis, St Denis de la Reunion, and Lagos; they each serve more than 500,000 OD passengers. As illustrated in Table 2, however, the leading African cities are still very modestly connected by airlines in comparison with the leading cities in the world.

Figure 1: The 25 most important cities in terms of origin and destination passengers. The OD flows are split into African and non-African inter-city flows. 


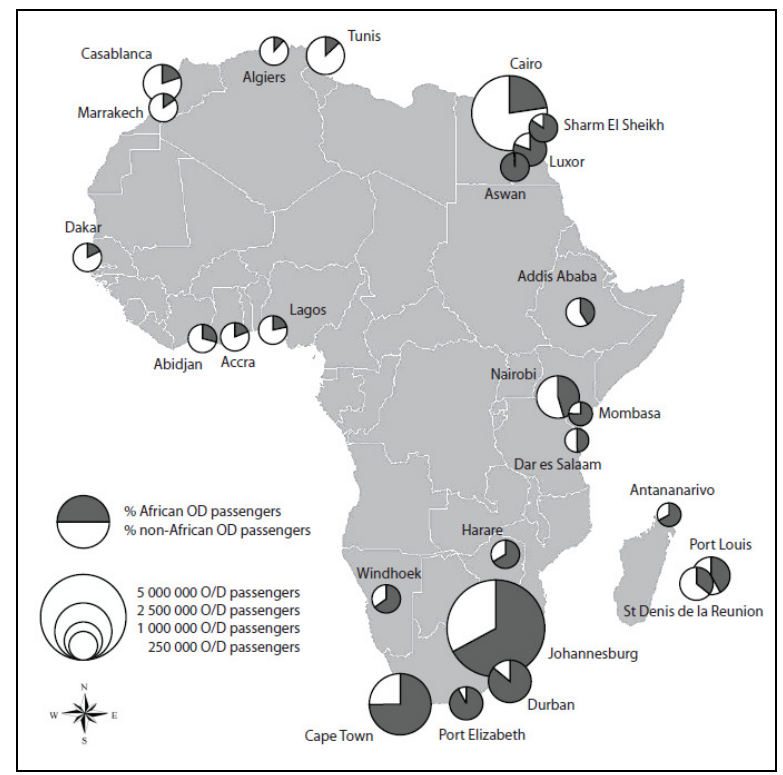

Source: Authors

Table2: A comparison between total O/D passengers for top African and Global cities in 2001

\begin{tabular}{|c|c|c|}
\hline Rank & City & Total Pax \\
\hline 1 & New York & $39.634,326$ \\
\hline 2 & London & $37.040,949$ \\
\hline 3 & Paris & $27.172,023$ \\
\hline 4 & Los Angeles & $22.275,951$ \\
\hline 5 & Chicago & $17.314,664$ \\
\hline 6 & San Francisco & $14.316,600$ \\
\hline 7 & Hong Kong & $13.441,397$ \\
\hline 8 & Miami & $13.037,033$ \\
\hline 9 & Frankfurt & $12.923,787$ \\
\hline 10 & Atlanta & $11.926,675$ \\
\hline \multicolumn{3}{|c|}{ African cities } \\
\hline 1 & Johannesburg & $5.763,055$ \\
\hline 2 & Cairo & $4.208,661$ \\
\hline 3 & Cape Town & $2.766,379$ \\
\hline 4 & Durban & $1.547,919$ \\
\hline 5 & Casablanca & $1.360,262$ \\
\hline 6 & Nairobi & $1.270,744$ \\
\hline 7 & Tunis & $1.219,443$ \\
\hline 8 & Port Louis & 960,941 \\
\hline 9 & Lagos & 542,913 \\
\hline 10 & St Denis de la Reunion & 540,093 \\
\hline
\end{tabular}

Source: compiled by authors 
As with Figure 1, Figure 2 extends this OD analysis to the top 111 African cities ${ }^{4}$. As the figure shows, the number of African cities with mostly African and non-African OD connections is almost equal. Most of the cities with mostly non-African OD connections are the continent's major cities; many of which are their respective nations' political and economic capitals. Thus, they are comparatively more connected globally relative to their smaller and politico-economically less significant counterparts. Stated differently, most of the cities above the line of best fit which are marked by high airline connectivity (i.e. at the top-right of the figure) are Africa's prospective global cities. Some smaller cities (e.g. Annaba, Tlemcen) may also be positioned above the regression line despite their low total connectivity because their proximity to major European or Middle Eastern destinations affords them relatively high non-African OD connections. On the other hand, cities below the regression line are mostly national or regional centres. Those that lie on the line of best fit, notably Sharm El Sheikh, Egypt, and Zanzibar, Tanzania, are relatively well connected globally by virtue of being large international tourist centres.

Figure 2: African and non-African inter-city OD flows for the top 111 African cities

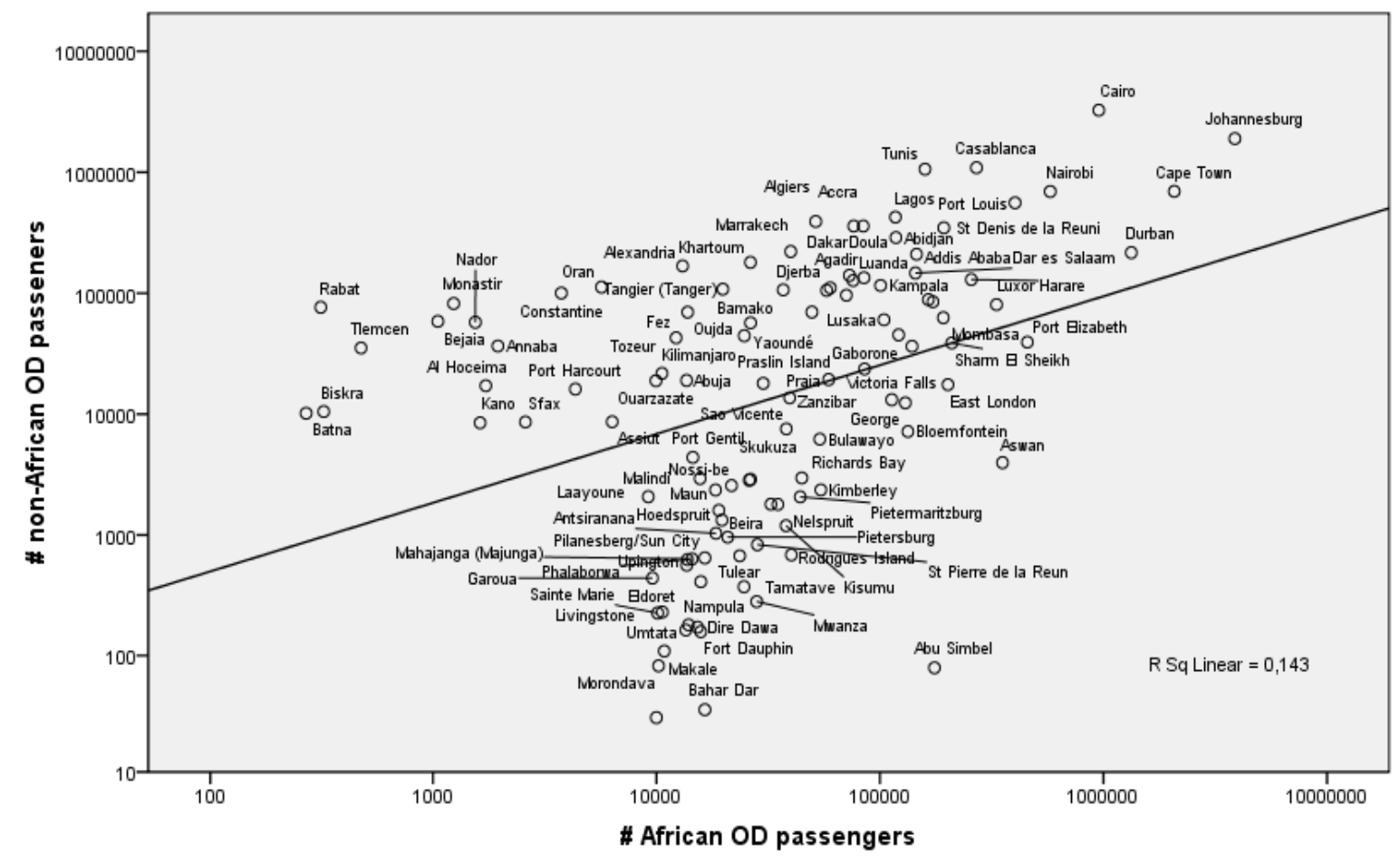

Source: authors

Besides this global picture of African OD connectivity, we utilize the 'urban hinterworld' concept to explore in greater detail the spatial connectivity of the major African air transport hubs of Durban, Johannesburg,

\footnotetext{
${ }^{4}$ As the variance in both variables is not constant over the entire data range (i.e. the variance in both variables dramatically increases with greater numbers of passengers), we transform both variables by taking their logarithm. This allows us to map the residuals over the entire data range. It might also be important to note that we are not measuring correlation, if any, between the number of African and Non-African OD passengers to avoid throwing readers off with the small $r^{2}(=0,14)$.
} 
Cairo, Casablanca, Nairobi, and Cape Town. The hinterworld of a city is its pattern of "relations with other cities across the world" (Taylor 2004, 145). This pattern of relations can be absolute i.e., a simple ranking of its O/D-connections (see Figure 3) or relative i.e., a weighted ranking of the importance of each of the city's O/D-connections vis-a-vis the total volume of passengers. The difference between these approaches can be illustrated as follows: suppose city $\mathrm{X}$ is connected to cities $\mathrm{Y}$ and $\mathrm{Z}$ by or through a volume of 50,000 passengers. City Y, however, serves a total of 1.000,000 passengers, while city Z merely serves 100,000 passengers. This implies that the connection $\mathrm{X}-\mathrm{Y}$ constitutes $5 \%$ of $\mathrm{Y}$ 's total connectivity, while the connection X-Z constitutes $50 \%$ of Z's total connectivity. In X's absolute hinterworld, Y and Z will be in the same rank while in $X$ 's relative hinterworld $Z$ will be considered ten times more important than $Y$. This distinction between a city's absolute and relative hinterworld is useful because it enables us to go beyond the major transnational linkages of African cities and explore, for instance, their national and regional air linkages.

Figures 3a-f show the absolute hinterworlds of Cairo, Casablanca, Durban, Cape Town, Johannesburg, and Nairobi in terms of each city's 20 most important OD links. ${ }^{5}$ Not surprisingly given their historical past, all these cities have strong connections to/from major European cities. However, all these cities also have unique connections that we wish to explore briefly.

Cairo: Because of its strong interrelations with the Arab and Muslim World, Cairo is most heavily linked to cities in the Greater Middle East such as Jeddah, Kuwait, Riyadh, and Dubai. In addition, it is well linked to major European and American cities such as Amsterdam, London, Paris and New York, (Figure 3a). Its strong Greater Middle Eastern linkages stem from the fact that it:

"represents the heart of the Arab countries ... [and] ... is the seat of almost 50 per cent of Arab political, economic, social, and cultural organizations...[like] the Arab League [...]. Cairo is considered the cultural centre of the Arab world; it is the Arab world's Hollywood. Arab tourism accounts for the highest proportion of tourism in Cairo [...]. As for the Muslim world, Cairo has played the leading role because of the existence of AlAzhar Mosque and University, which have disseminated Islamic knowledge and thought for centuries. A substantial educational exchange of students and scholars links Cairo with most Muslim countries" (Yousry, Abu-Zekry and Yousry, 1998: 277).

Moreover, besides its "centres of higher learning, splendid museums, world-class theatre and music, and magnificent mosques and Islamic learning centres" (de Blij and Muller 2008: 366), Cairo's strong interconnections with the Arab and Muslim world stems from (i) its place at the top of the Arab urban hierarchy (ibid.), (ii) its role in western geostrategic initiatives in the Greater Middle East, and (iii) its geographically favourable location at the confluence of Africa, Asia and Europe (ibid., Yousry, Abu-Zekry and Yousry 1998, el-Khishin 2003).

\footnotetext{
${ }^{5}$ As a matter of clarity, links below 10000 passengers have the same thickness. This only applies to Durban which has ten links with 5000 to 10000 passengers in its top twenty connections.
} 
Casablanca: As the financial and business centre of Morocco, a former French colony that still uses French as its official language, Casablanca has strong connections to major French-speaking cities such as Paris, Marseilles, Tunis, Lyon, and Montreal (Figure 3b). In addition to its strong European leaning, the city is also well connected to major world cities such as Milan, Brussels, Amsterdam and New York. And since Morocco is part of the wider Arab cultural zone, it is also connected to Tunis, Jeddah, Cairo and Riyadh. Within Morocco, Casablanca is strongly connected to Agadir and Marrakech.

Durban, Cape Town, and Johannesburg: These cities are well interconnected with each other with the most important link among them being the Cape Town-Johannesburg one with 1.406,897 OD passengers (Figures $3 \mathrm{c}, \mathrm{d}$ and e). With 830,192 OD passengers, the Johannesburg- Durban link is half the size of its JohannesburgCape Town counterpart.

Looked at individually, Cape Town, Johannesburg and Durban, each have additional unique connections. As Figure 3c shows, Durban is relatively more connected with the Eastern world (i.e. South Asia, Middle East and Oceania) because of its historically large Asian population (Beall and Todes 2004). Conversely, Cape Town (Figure 3d) is relatively more connected to the Western part of the world (i.e. Europe and the US) given its historically large European population and attraction to many European leisure and business tourists (Lemanski 2007).

On its part, Johannesburg is well connected to the rest of Africa and Europe and is by far the most dominant African city in terms of OD connections to/from major cities (Figure 3e). This is a reflection of (i) the city's importance as a true African world city (Taylor 2001) with "[...] the largest mining and industrial center on the African continent [...] Africa's largest stock exchange [...] [and] most diverse manufacturing sector [...]" (Myers and Owusu 2008: 374), (ii) its large and wealthy population and sophisticated economy, (iii) its high leisure and business tourism (Simon 1992: 85, Simon 1995: 139-140, Beavon 1998: 358-359), (iv) its O.R. Tambo International Airport (JNB) -- Africa's busiest airport (Myers and Owusu 2008: 374) with an annual passenger volume of nearly 17 million travellers and nearly 50 different airlines (www.acsa.co.za, Beavon 1998: 358, SAinfo, June 2009), many of which fly there directly (Keeling 1995: 122-124), and (v) its overall dominance of the African air network (Figure 1) and its high position in the broader global air and urban network (Table 1, Keeling 1995: 122-124).

Nairobi: Besides being Kenya's capital, Nairobi is "the commercial, industrial, financial, educational, and communication hub for Eastern and Central Africa" and is one of the "major international air transport hubs in Sub-Saharan Africa" more so for tropical Africa (Otiso and Owusu 2008: 153). In particular, the city's major non-African OD links are to London, Dubai, Mumbai and Amsterdam. Locally and regionally, Nairobi is linked strongly to Mombasa (Kenya), Johannesburg, and Kampala. Nairobi's strong connections to Europe, the Middle East, Asia and North America pertain to its being: (i) the regional headquarters of many 
multinational corporations, (ii) the gateway to East Africa and the core of the region's dominant economy, (iii) global headquarters of the United Nations Environment Program (UNEP) and the United Nations Human Settlements Program (UNHABITAT) and, (iv) host to one of the largest concentrations of secretariats of international organizations in Africa especially nongovernmental organizations (NGOs) and foreign country embassies (Otiso and Owusu 2008: 153). While its strong links to London date to the 1900-1963 British colonial rule of Kenya, its links to Dubai are fairly new and are the result of Dubai's popularity with business people as a source of many consumer goods sold in Kenya and surrounding countries. Conversely, Nairobi's links to Mumbai stem from the business activities of Kenya's large Kenyan-Asian community that is historically descended from Pakistan and Western India (Myers and Owusu 2008). For these reasons, Nairobibased Kenya Airways, one of continental Africa's dominant airlines, operates many flights to Dubai and Mumbai. Nairobi's strong links with Mombasa are due to Mombasa's role as (i) Kenya's second largest city and commercial center, (ii) the center of Kenya's large Indian Ocean tourism business, and (iii) Kenya's, and indeed East Africa's, main Indian Ocean port (Otiso 2005).

Figure 3 (a-f): the 20 most important OD links of Cairo, Casablanca, Durban, Cape Town, , Johannesburg, and Nairobi .

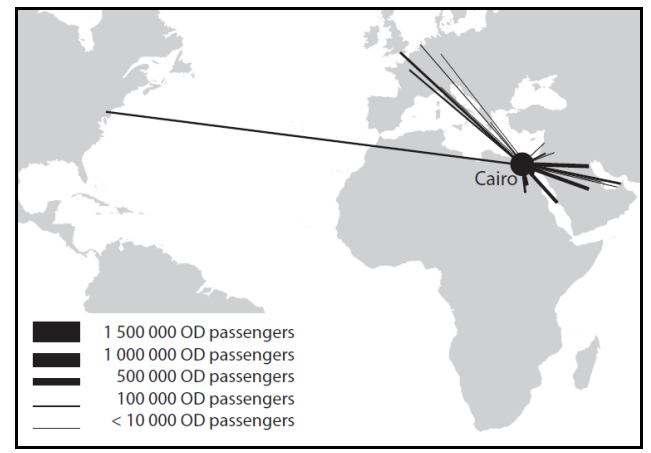

(a)

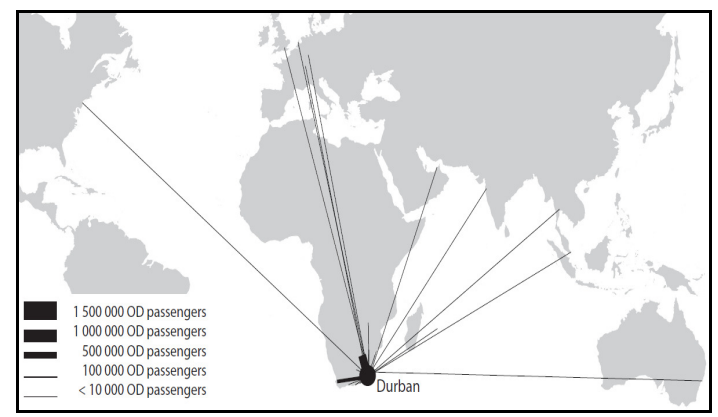

(c)

(b)
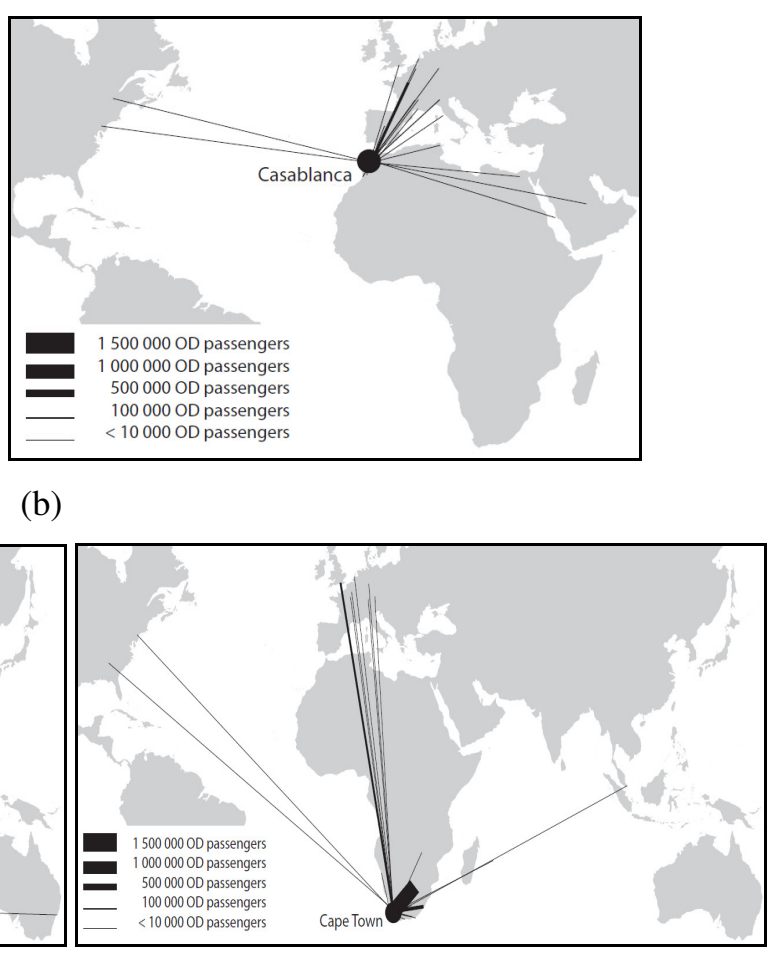

(d) 


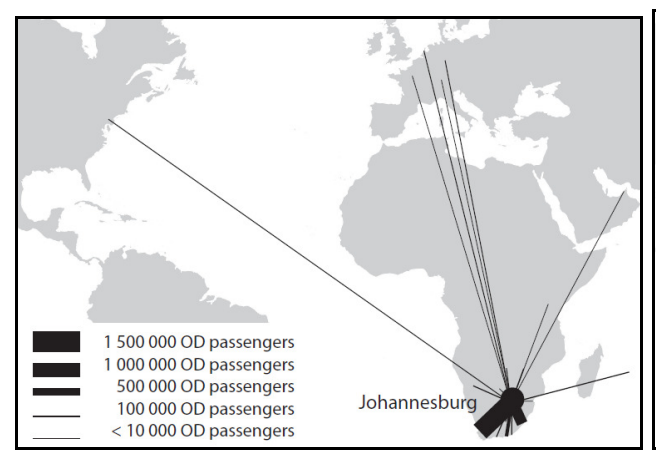

(e)

Source: Authors

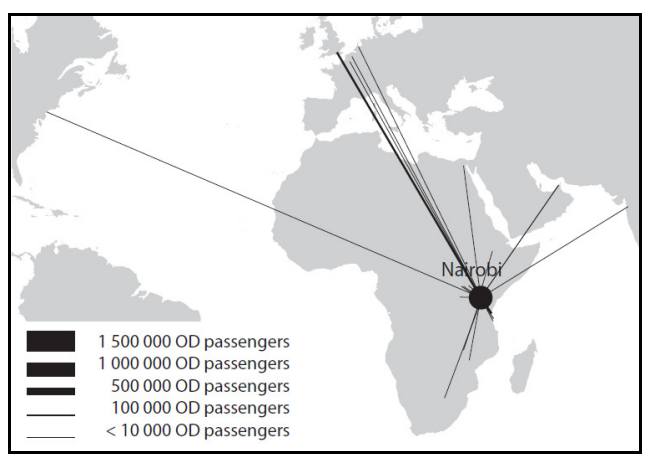

(f)

Before examining the 'relative hinterworld' of Cairo, Casablanca, Durban, Cape Town, and Nairobi, we first take a detailed look at the relative hinterworld of the most dominant city of the set: Johannesburg. In Figure 4, we present Johannesburg's overall O/D-connections and total passenger volume. ${ }^{6}$ The Y-axis presents the total number of OD passengers for the cities to which Johannesburg is connected, whereas the $\mathrm{X}$-axis shows the size of the link, i.e. the number of passengers, between Johannesburg and these cities. This allows us to assess the importance of the individual links in light of the importance of the connected city. Thus, cities positioned close to the line of equality have relatively strong linkages 'overlinkage' to Johannesburg, while cities positioned further above the line are 'underlinked' as they have a weaker link to Johannesburg than could be expected from their total passenger size.

As evident from Figure 4, there is a clear division between the city's African and non-African links. Specifically, in spite of the high total passenger volume, Johannesburg is 'underlinked' with its non-African city counterparts. The opposite situation is true of the relationship between Johannesburg and many Southern African cities; which implies that Johannesburg is a critical cog in the Southern African regional air transport network. Thus, although Johannesburg is well-connected to cities such as Paris, New York, and London, its OD connections with African cities, in particular Southern African cities, are far more important and are in line with the growing "'Africanisation' of South Africa's international air links" since independence (i.e., since majority rule commenced) in 1994 (Pirie 2006: 3).

Figure 4: The relationship between the total $O D$ pax and the link OD pax for all OD connections with Johannesburg $^{7}$

\footnotetext{
${ }^{6}$ The lower limit for the total OD passenger volume is 10,000 and 5,000 for the OD passenger volume on the OD connection.

${ }^{7}$ In Figure 4, "Southern African cities" refers to cities in South Africa, Angola, Botswana, Lesotho, Swaziland, Namibia, Zambia, Mozambique, and Zimbabwe.
} 


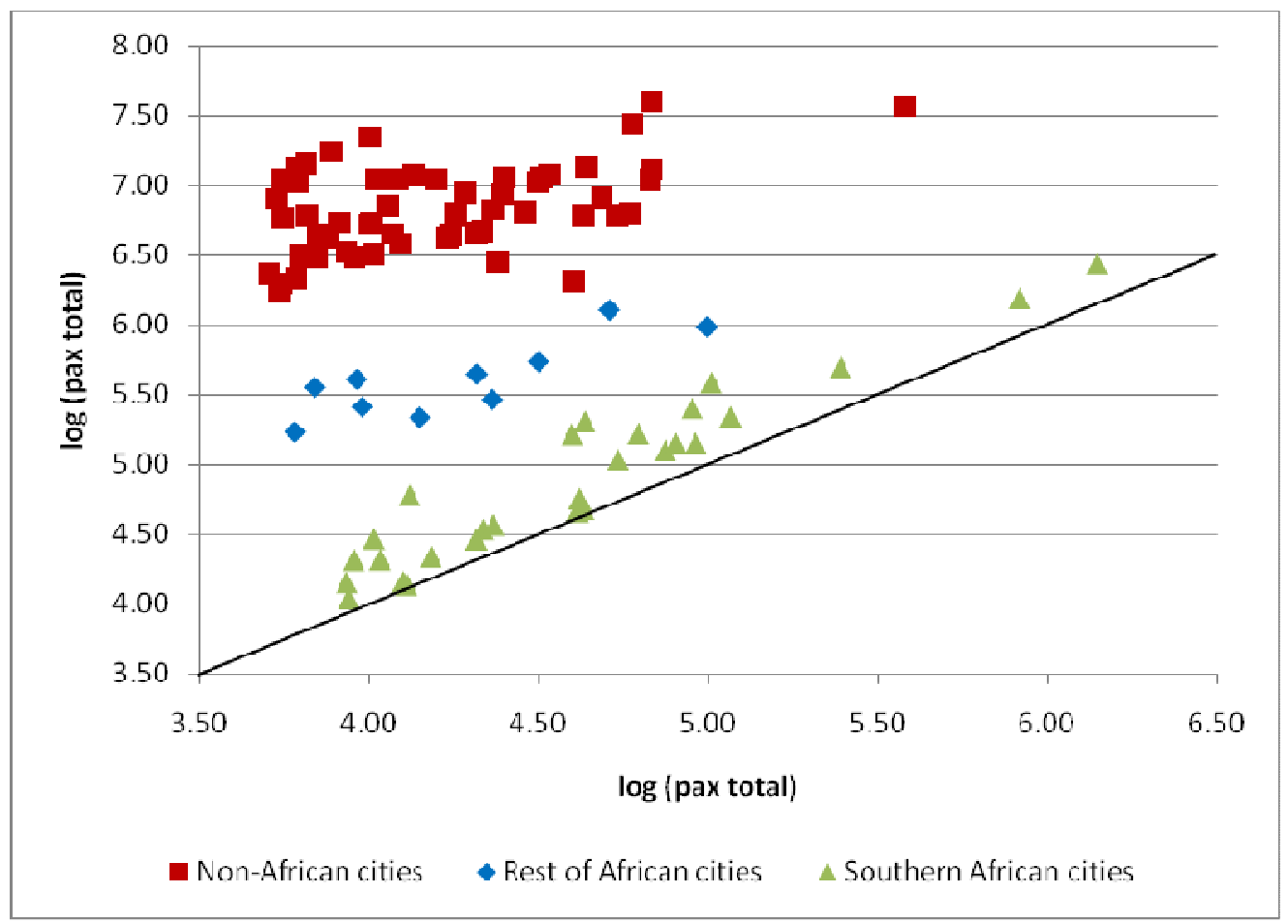

Table 3, on the other hand, shows the relative hinterworlds of Johannesburg, Durban, Cape Town, Cairo, Nairobi, and Casablanca through connections with their top 10 city partners i.e. those cities close to the line of equality. As shown in Table 3, Johannesburg's relative hinterworld is most striking because its top 16 partner cities are almost exclusively oriented towards Johannesburg in that more than $50 \%$ of their O/D-connections consist of ties to/from Johannesburg -- further proof that Johannesburg is Southern Africa's dominant air transportation centre. This is more so striking since, even though Cape Town and Durban are also well-known cities, they do not have such an unambiguous place as Johannesburg in the Southern African air transport network even though their most important linkages, in relative terms, are also largely centred on cities in the immediate region. ${ }^{8}$ It is, perhaps, useful to note here that Johannesburg's dominance is not due to any data bias since our data reflect genuine O/D-flows. Looking at the Northern African cities, a clear-cut domination on Northern Africa is also far less discernable for Cairo and Casablanca, even though they both dominate their own countries.

Conversely, Nairobi dominates its relative hinterworld more so within Kenya. Regionally, Bujumbura (Burundi), Dar es Salaam and Zanzibar (Tanzania) and Kampala (Uganda), are fairly well oriented to Nairobi thanks in no small part to the city's role as the hub of one of the region's major airlines i.e., Kenya Airways. Nairobi's dominant role in Eastern Africa is also supported by other studies (e.g., Pedersen 2001).

Table 3: The relative hinterworld of Johannesburg, Durban, Cape Town, Cairo, Casablanca, and Nairobi.

\footnotetext{
${ }^{8}$ For Durban and Cape Town, Southern African cities are less close to the line of equality values in comparison to their position in Figure 4 (Johannesburg). This means that they are less 'overlinked' than in the Johannesburg case. Regional African cities, on the other hand, are still closer to the line of equal values than non-African cities.
} 


\begin{tabular}{|l|l|l|}
\hline \multicolumn{2}{|l}{ Johannesburg, South Africa } \\
\hline Country & City (relative share of link to Johannesburg) & $\begin{array}{l}\text { Number } \\
\text { of cities }\end{array}$ \\
\hline South Africa & $\begin{array}{l}\text { Umtata (94\%); Richards Bay (91\%); Pietermaritzburg (89\%); } \\
\text { Phalaborwa (88\%); Kimberley (74\%); Skukuza (72\%); Pietersburg } \\
(70 \%)\end{array}$ & 7 \\
\hline Zambia & Livingstone (80\%) & 1 \\
\hline Lesotho & Maseru (69\%) & 1 \\
\hline Swaziland & Manzini (65\%) & 1 \\
\hline Total & & 10 \\
\hline
\end{tabular}

\begin{tabular}{|l|l|l|}
\hline \multicolumn{2}{|l|}{ Durban, South Africa } \\
\hline Country & City (relative share of link to Durban) & $\begin{array}{l}\text { Number } \\
\text { of cities }\end{array}$ \\
\hline South Africa & $\begin{array}{l}\text { Nelspruit (17\%); Port Elizabeth (17\%); Johannesburg (14\%); East } \\
\text { London (13\%); Cape Town (11\%); Bloemfontein (9\%); George } \\
(5 \%)\end{array}$ & 7 \\
\hline Zimbabwe & Harare (2\%) & 1 \\
\hline Mauritius & Port Louis (2\%) & 1 \\
\hline India & Mumbai (0,2\%) & 1 \\
\hline Total & & 10 \\
\hline
\end{tabular}

\begin{tabular}{|c|c|c|}
\hline \multicolumn{3}{|c|}{ Cape Town, South Africa } \\
\hline Country & City (relative share of link to Cape Town) & $\begin{array}{l}\text { Number } \\
\text { of cities }\end{array}$ \\
\hline South Africa & $\begin{array}{l}\text { Pilanesberg/Sun City (56\%); Hoedspruit (35\%); Johannesburg } \\
(24 \%) \text {; Bloemfontein (24\%); George (20\%); Port Elizabeth }(20 \%) \text {; } \\
\text { Durban (20\%); Kimberley (19\%); East London (17\%) }\end{array}$ & 9 \\
\hline Namibia & Walvis Bay (39\%) & 1 \\
\hline Total & & 10 \\
\hline
\end{tabular}

\begin{tabular}{|c|c|c|}
\hline \multicolumn{3}{|l|}{ Cairo, Egypt } \\
\hline Country & City (relative share of link to Cairo) & $\begin{array}{l}\text { Number } \\
\text { of cities }\end{array}$ \\
\hline Egypt & $\begin{array}{l}\text { Sharm El Sheikh (76\%); Hurghada (76\%); Luxor (70\%); Aswan } \\
(51 \%) \text {; Assiut (41\%); Abu Simbel }(13 \%)\end{array}$ & 6 \\
\hline $\begin{array}{ll}\text { United } & \text { Arab } \\
\text { Emirates } & \end{array}$ & Ras Al Khaymah (36\%); Al Ain (23\%) & 2 \\
\hline Kuwait & Kuwait (13\%) & 1 \\
\hline Syria & Aleppo (10\%) & 1 \\
\hline Total & & 10 \\
\hline
\end{tabular}

\begin{tabular}{|l|l|l|}
\hline Casablanca, Morocco & $\begin{array}{l}\text { Number } \\
\text { of cities }\end{array}$ \\
\hline Country & City (relative share of link to Casablanca) & 7 \\
\hline Morocco & $\begin{array}{l}\text { Laayoune (57\%); Agadir (35\%); Ouarzazate (34\%); Fez (17\%); } \\
\text { Oujda (15\%); Marrakech (14\%); Tangier (Tanger) (12\%) }\end{array}$ \\
\hline Tunisia & Tunis (4\%) & 1 \\
\hline Algeria & Algiers (2\%) & 1 \\
\hline Senegal & Dakar (2\%) & 1 \\
\hline
\end{tabular}




\begin{tabular}{|l|l|l|}
\hline Nairobi, Kenya & & \\
\hline Country & City (relative share of link to Durban) & $\begin{array}{l}\text { Number } \\
\text { of cities }\end{array}$ \\
\hline Kenya & Kisumu (94\%); Eldoret (94\%); Malindi (75\%); Mombasa (68\%) & 4 \\
\hline Burundi & Bujumbura (56\%) & 1 \\
\hline Tanzania & Zanzibar (45\%), Dar es Salaam (12\%) & 2 \\
\hline Rwanda & Kigali (32\%) & 1 \\
\hline Uganda & Kampala (26\%) & 1 \\
\hline Malawi & Lilongwe (11\%) & 1 \\
\hline Total & & 10 \\
\hline
\end{tabular}

\section{4b. Cities as hubs: connectivity and spatiality}

A major advantage of the MIDT data is that we have, besides information on the actual OD flows, information about the hub function of a city (see Derudder et al. 2007a). The whole idea of hubs is that passengers make onward connections, but such information is not registered in standard airline databases because they customarily gauge the individual legs of O/D connections rather than the connections in their entirety. Since our data contain hub ${ }^{9}$ information, we are able to examine the gateway function of major African cities even though the African airline network is not that developed. The gateway connectivity of a city is potentially an important complement to mere O/D-connectivity because cities mediating flows between other nodes possibly serve as brokers in the overall urban network (see Alderson and Beckfield 2004). Such cities may derive a large part of their overall connectivity from their 'gateway function' in urban networks.

In what follows, we explore in detail the spatial gateway connectivity or the absolute and relative 'hubness' of various African cities with particular emphasis on the four cities at the top of Table 4, that is, Johannesburg, Casablanca, Nairobi and Addis Ababa (see Derudder et al. 2007a). While the absolute hub intensity of a node (denoted $\mathrm{AH}$ ) is measured by the total number of passengers that use it to make an onward connection, the relative hub intensity of a node (denoted $\mathrm{RH}$ ) is obtained by dividing the number of hub passengers by all passengers that make use of a given node. If $\mathrm{RH}=0$, then the city functions as a pure origin/destination node. If $\mathrm{RH}=1$, then the node functions exclusively as an intermediate switching point for passenger traffic (see Derudder et al. 2007a).

A number of important observations are evident in Table 4. First, is the overwhelmingly dominant position of Johannesburg in terms of absolute hubness, with more than 800,000 hub passengers using the city to connect to other destinations in the period under investigation. Second, Addis Ababa and Casablanca outrank Johannesburg and Nairobi in relative hubness though Addis Ababa's absolute 'hubness' is lower than Nairobi's. Third, Cape Town, Tunis, Port Louis, Cairo, Accra and Algiers are clearly 'dead-ends' in the urban

\footnotetext{
${ }^{9}$ Hubs have become increasingly important in airline networks due to the increased adoption of the hub-and-spoke model as the primary strategy for organizing route structures. The hub-and-spoke model looks like a bicycle wheel with a core component (the hub) and many subcomponents (the spokes).
} 
network because they hardly redirect flows to other cities as Johannesburg, Casablanca, Nairobi and Addis Ababa do (see Table 5). While the 'dead endedness' of Cairo and Cape Town is especially striking since they are relatively well connected in and of themselves (see Figure 1), this situation arises because both cities are large tourist destinations with large numbers of passengers that end their trips there instead of using them to connect to other places.

Moreover, the absolute and relative 'hubness' of the various cities in Table 4 is for the most part a product of their locations, the competitive structure of their respective airline markets, and the route configurations of their dominant airlines. For instance, the high absolute and relative 'hubness' of Johannesburg, Nairobi, and Addis Ababa is respectively tied to the headquartering and route configurations of South African Airways, Kenya Airways, and Ethiopian Airlines. All three airlines respectively funnel large numbers of passengers to their hubs in Johannesburg, Nairobi, and Addis Ababa before flying them to their final African and nonAfrican destinations. Addis Ababa's high relative 'hubness' is expected to be amplified further when Ethiopian Airlines' quest for membership in the Star Alliance becomes effective. Besides, the airline has recently helped launch the Togo-based ASKY airlines thereby gaining more connecting passengers from West Africa. Additionally, as the headquarters of one of Africa's largest airlines (Ethiopian Airlines), Addis Ababa's 'hubness' and standing within the African and global transnational urban network has benefitted immensely from its role as the home of the United Nations Economic Commission for Africa as well as the African Union. Although the latter role essentially makes Addis Ababa the administrative capital of Africa, the city's place in the African and global transnational urban network is lower than nearby Nairobi's which hosts more international agencies, has a more sophisticated economic base, and a much larger global imprint (Simon 1992:83-88).

Table 4: The absolute and relative hubness of African hubs in 2001 (cities with more than 10000 hub passengers).

\begin{tabular}{|l|l|l|l|}
\hline Hub & Country & AH & RH \\
\hline Johannesburg & South Africa & 806,577 & 0,12 \\
\hline Casablanca & Morocco & 288,201 & 0,17 \\
\hline Nairobi & Kenya & 179,342 & 0,12 \\
\hline Addis Ababa & Ethiopia & 102,950 & 0,22 \\
\hline Cairo & Egypt & 97,000 & 0,02 \\
\hline Sal & Cape Verde Islands & 28,973 & 0,15 \\
\hline Libreville & Gabon & 23,492 & 0,16 \\
\hline Abidjan & Cote D'Ivoire & 22,293 & 0,05 \\
\hline Tunis & Tunisia & 20,855 & 0,02 \\
\hline Mahe Island & Seychelles & 20,538 & 0,11 \\
\hline Aswan & Egypt & 20,306 & 0,05 \\
\hline
\end{tabular}




\begin{tabular}{|l|l|l|l|}
\hline Port Louis & Mauritius & 17,509 & 0,02 \\
\hline St Denis de la Reunion & Reunion Island & 15,045 & 0,03 \\
\hline Doula & Cameroon & 14,542 & 0,06 \\
\hline Cape Town & South Africa & 14,205 & 0,01 \\
\hline Abu Simbel & Egypt & 12,425 & 0,07 \\
\hline Accra & Ghana & 10,997 & 0,02 \\
\hline Algiers & Algeria & 10,977 & 0,02 \\
\hline
\end{tabular}

Source: Authors

In addition to the absolute and relative 'hubness' of the cities in Table 4, we decided to extend the analysis further by calculating a simple measure of 'internationality' for the top four hubs ${ }^{10}$ in Table 4 because the measure serves to distinguish between African, non-African, and mixed African/non-African hub functionality. Thus, a hub function is deemed (i) 'non-African' if it involves connections between two nonAfrican cities (e.g. Johannesburg is a hub in the London-Mumbai connection), (ii) 'African' if it involves connections between two African cities (e.g. Nairobi is hub in the connection Mombasa-Cairo), and (iii) 'mixed' if it involves connections between an African and a non-African city (e.g. Casablanca is a hub in the connection Brussels-Agadir). ${ }^{11}$ Table 5 summarizes the 'internationality' measures for Johannesburg, Casablanca, Nairobi and Addis Ababa.

Table 5: Hub passengers (mixed, international, regional)

\begin{tabular}{|l|l|l|l|l|l|}
\hline Hub City & $\begin{array}{l}\text { Total } \\
\text { hubpax }\end{array}$ & $\begin{array}{l}\text { Relative } \\
\text { Hubness }\end{array}$ & $\begin{array}{l}\text { \% Afr. } \\
\text { hubpax }\end{array}$ & $\begin{array}{l}\text { \% non-Afr. } \\
\text { hubpax }\end{array}$ & $\begin{array}{l}\text { \% mixed } \\
\text { hubpax }\end{array}$ \\
\hline Johannesburg & 806,577 & $12 \%$ & $22 \%$ & $1 \%$ & $77 \%$ \\
\hline Casablanca & 288,201 & $17 \%$ & $4 \%$ & $0 \%$ & $95 \%$ \\
\hline Nairobi & 179,342 & $12 \%$ & $18 \%$ & $0 \%$ & $82 \%$ \\
\hline Addis Ababa & 102,950 & $22 \%$ & $9 \%$ & $4 \%$ & $86 \%$ \\
\hline
\end{tabular}

Source: Authors

As Table 5 shows, the African hubs largely function as major gateways between African and non-African cities (i.e. mixed). Johannesburg, Nairobi and Addis Ababa also control a significant part of their regional traffic. Figures 4 (a, b) illustrate the basic spatiality of the ('internationality') hub functions of Casablanca and Johannesburg using each city's most important hub connections, i.e., those with more than 10,000 passengers. This leads to 17 connections for Casablanca and 20 for Johannesburg. We do not show the spatial patterns of Nairobi and Addis Ababa because they have, respectively, only 9 and 4 connections with 10,000 or more passengers. Taken together, the maps once again reveal that Johannesburg is the most dominant hub in Africa as well as South Africa given its role in connecting Durban and Cape Town as well as other African another

\footnotetext{
${ }^{10}$ i.e. the top four cities with more than 100,000 hub passengers.

${ }^{11}$ In case of two hubs, the connections are classified in the same fashion.
} 
(non-) African cities. Casablanca largely functions as a switching point between Europe and Morocco and points to the possibility that location is one of the central influences on a city's 'internationality'. Johannesburg and Nairobi also have a higher internationality index due to the international connections of their respective host nations' relatively large domestic European populations (Pedersen 2001).

Figure 4(a, b): The basic spatiality of the hub function of Casablanca and Johannesburg
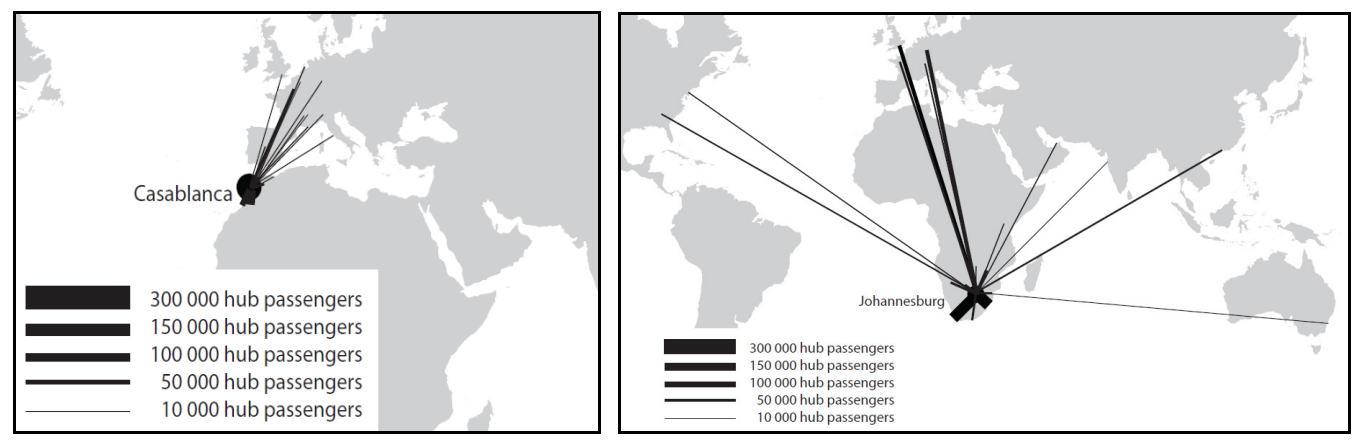

Source: Authors

\section{Conclusions and Avenues for Further Research}

We mainly set out to contribute to the literature on the globalization of African cities in the global era (i.e., since the 1980s) through an analysis of African airline connectivity and the position of African cities in the global urban airline network. Since transport and communications are critical components of the global economy (Cidell 2006, Hummels 2007), a clear understanding of Africa's airline connectivity is integral to our understanding of the globalization and global rank of African cities.

From the foregoing analysis, it is evident that Africa is still not as well integrated into the global economy from an airline connectivity standpoint. Moreover, the continent's cities do not rank high on the global urban network despite significant increases in their globality in the current globalization phase (Otiso and Owusu 2008, Grant 2009). Nevertheless, some African cities, notably Johannesburg, Cairo, Cape Town, Nairobi, Casablanca, Durban, and Tunis have become important cogs in Africa's air transport network (Figure 1). Some of these cities, notably Johannesburg, Cairo, Cape Town, Nairobi, Casablanca, and Durban, are also relatively well integrated into the global urban airline network. Thus, they measure up relatively well on global urban networks as measured by air connectivity. Nevertheless, Johannesburg is by far Africa's most important global air transport hub (Pedersen 2001, Pirie 2006) and has the continent's highest number of passengers or absolute 'hubness' besides being Africa's main world city (Otiso and Owusu 2008, Myers and Owusu 2008). Overall, South African cities (especially Johannesburg and Cape Town) dominate the African airline network even as Cairo and Nairobi have respectively remained the key hub cities in northern and eastern Africa.

That Africa's airline connectivity is still poor is evident from the fact that most of the cities identified above mostly handle non-African passenger flows. Since air travel generally increases with economic development, 
it is not surprising that Johannesburg and other southern African cities, with their generally higher level of economic development, mostly handle more African than non-African passengers (Pirie 2006) besides their larger overall passenger volume (Figure 1).

Whereas southern, eastern, and northern Africa respectively have Johannesburg, Nairobi and Cairo as their dominant airline hubs, western and central Africa had no such hub in 2001 (Figure 1). This is mainly due to the two regions' lack of a key continental airline comparable to southern Africa's South African Airways, northern Africa's Royal Air Maroc and EgyptAir, and eastern Africa's Ethiopian Airlines, Kenya Airways, and Air Mauritius. While this situation has benefited the other continent's key airlines e.g., South African Airways and Kenya Airways (Pirie 2006), it also does mean that no western and central African airport handled as many passengers as the hub airports of Johannesburg, Nairobi, and Cairo in 2001. Nevertheless, current evolutions, such as the establishment of a small Congolese subsidiary by South African airlines and the 2010 launch of the Ethiopian Airways-affiliated ASKY Airlines, can perhaps be read as the first signs that this general decline is coming to an end.

Indeed as Table 6 shows, there have been a lot of changes in the air connectedness of the leading 25 African cities in the 2001 and 2009 period. As the table shows, while Johannesburg, Cairo, and Cape Town still retain their place at the top of the African urban air connectedness hierarchy, most of the other 25 cities have experienced major changes in their ranks in that period with 10 cities rising, 11 dropping, and one (Casablanca) maintaining its 2001 place. Those that gained in rank, in order of least to most gain (in brackets), include Tunis (1), Dakar (1), Mombasa (2), Windhoek (2), Addis Ababa (3), Dar es Salaam (3), Lagos (5), Algiers (5), Marrakech (11), and Sharm El Sheikh (13). Three of the last four cities are located in North Africa while Lagos is in West Africa. The 11 cities that experienced a drop in rank between 2001 and 2009, in order of most to least loss in rank (in brackets), include Port Elizabeth (9), Harare (9), St Denis de la Reunion (5), Aswan (5), Durban (4), Nairobi (3), Port Louis (3), Luxor (3), Abidjan (3), Antananarivo (2), and Accra (1). In terms of regional distribution, most of the cities that lost rank are in Southern Africa (Port Elizabeth, Durban, Harare and Antananarivo) and Eastern Africa (St Denis de la Reunion, Nairobi, and Port Louis). Still the 2009 data indicate the persistent absence of well-connected central African city into the continent's airline network even though Lagos seems to have become one such city in West Africa. 


\begin{tabular}{|c|c|c|c|c|c|c|c|c|}
\hline $\begin{array}{l}2001 \\
\text { Rank }\end{array}$ & City & Country & $\begin{array}{c}\text { OD } \\
\text { passengers } \\
2001(G N) \\
\end{array}$ & $\begin{array}{l}2009 \\
\text { Rank } \\
\end{array}$ & $\begin{array}{c}\text { OD } \\
\text { passengers } \\
2009(G N) \\
\end{array}$ & $\begin{array}{c}\text { Change in OD } \\
\text { passengers 2001- } \\
2009 \text { (GN) }\end{array}$ & $\begin{array}{c}2001-2009 \\
\text { rank change }\end{array}$ & $\begin{array}{c}\text { Percent Change } \\
\text { in OD passengers } \\
2001-2009 \text { (GN) }\end{array}$ \\
\hline 1 & Johannesburg & South Africa & $5,763,055$ & 1 & $11,689,885$ & $5,926,830$ & $=$ & 103 \\
\hline 2 & Cairo & Egypt & $4,208,661$ & 2 & $11,188,564$ & $6,979,903$ & $=$ & 166 \\
\hline 3 & Cape Town & South Africa & $2,766,379$ & 3 & $6,468,511$ & $3,702,132$ & $=$ & 134 \\
\hline 4 & Durban & South Africa & $1,547,919$ & 8 & $3,478,344$ & $1,930,425$ & $\downarrow(4)$ & 125 \\
\hline 5 & Casablanca & Morocco & $1,360,262$ & 5 & $4,695,357$ & $3,335,095$ & $=$ & 245 \\
\hline 6 & Nairobi & Kenya & $1,270,744$ & 9 & $3,353,714$ & $2,082,970$ & $\downarrow(3)$ & 164 \\
\hline 7 & Tunis & Tunisia & $1,219,443$ & 6 & $3,983,108$ & $2,763,665$ & $\uparrow(1)$ & 227 \\
\hline 8 & Port Louis & Mauritius & 960,941 & 11 & $2,091,513$ & $1,130,572$ & $\downarrow(3)$ & 118 \\
\hline 9 & Lagos & Nigeria & 542,913 & 4 & $6,269,189$ & $5,726,276$ & $\uparrow(5)$ & 1,055 \\
\hline 10 & St Denis de la Reunion & la Reunion & 540,093 & 15 & $1,432,359$ & 892,266 & $\downarrow(5)$ & 165 \\
\hline 11 & Port Elizabeth & South Africa & 495,646 & 20 & $1,085,317$ & 589,671 & $\downarrow(9)$ & 119 \\
\hline 12 & Algiers & Algeria & 442,791 & 7 & $3,644,216$ & $3,201,425$ & $\uparrow(5)$ & 723 \\
\hline 13 & Accra & Ghana & 442,737 & 14 & $1,471,975$ & $1,029,238$ & $\downarrow(1)$ & 232 \\
\hline 14 & Dakar & Senegal & 435,031 & 13 & $1,590,100$ & $1,155,069$ & $\uparrow(1)$ & 266 \\
\hline 15 & Luxor & Egypt & 412,665 & 18 & $1,262,163$ & 849,498 & $\downarrow(3)$ & 206 \\
\hline 16 & Abidjan & Ivory Coast & 406,091 & 19 & $1,087,823$ & 681,732 & $\downarrow(3)$ & 168 \\
\hline 17 & Harare & Zimbabwe & 385,909 & 25 & 535,438 & 149,529 & $\downarrow(8)$ & 39 \\
\hline 18 & Aswan & Egypt & 357,483 & 23 & 640,788 & 283,305 & $\downarrow(5)$ & 79 \\
\hline 19 & Addis Ababa & Ethiopia & 355,481 & 16 & $1,398,549$ & $1,043,068$ & $\uparrow(3)$ & 293 \\
\hline 20 & Dar es Salaam & Tanzania & 290,966 & 17 & $1,302,030$ & $1,011,064$ & 个(3) & 347 \\
\hline 21 & Marrakech & Morocco & 260,960 & 10 & $2,890,128$ & $2,629,168$ & $\uparrow(11)$ & 1,007 \\
\hline 22 & Antananarivo & Madagascar & 257,416 & 24 & 554,534 & 297,118 & $\downarrow(2)$ & 115 \\
\hline 23 & Mombasa & Kenya & 254,703 & 21 & 817,214 & 562,511 & $\uparrow(2)$ & 221 \\
\hline 24 & Windhoek & Namibia & 253,140 & 22 & 687,450 & 434,310 & $\uparrow(2)$ & 172 \\
\hline 25 & Sharm El Sheikh & Egypt & 248,476 & 12 & $2,011,620$ & $1,763,144$ & $\uparrow(13)$ & 710 \\
\hline
\end{tabular}


In spite of the rank changes that the 25 cities experienced between 2001 and 2009, they all witnessed substantial increases in passenger volume, which points to the growing popularity of air transport in Africa. Yet this increase in passenger volume varied widely among these cities, with the least increase being experienced by Harare, Zimbabwe $(149,529)$ and the most by Cairo, Egypt $(6,979,903)$. In terms of percent gain in passengers between 2001 and 2009, the lowest gain was by Harare, Zimbabwe (39\%) while the most was by Marrakech, Morocco (1,007\%). Equally notable is Lagos, Nigeria with its large increase in passenger volume (i.e., 5,726,276 or 1,054\%) between 2001 and 2009. The substantial gains of Lagos in both rank and passenger volume point to its emergence as a major hub in West Africa. The four cities that saw no change in their ranks generally experienced large increases in passenger volume. Thus, Johannesburg grew its volume by 5,926,830 (103\%), Cairo by 6,979,903 (166\%), Cape Town by 3,702,132 (134\%) and Casablanca by $3,335,095$ (245\%) thereby indicating these cities continued central role in the African air transport network. Besides gaining 5,726,276 passengers, Lagos also had the fourth largest passenger volume (i.e., 6,269,189) in 2009, thus making it the fourth busiest airport in Africa after Johannesburg, Cairo, and Cape Town.

These changes in the airline connectedness of the leading 25 African cities in the 2001 to 2009 period raise a number of questions that we hope to explore in the future. First, what factors account for the rank changes among these cities? Second, which airline/airlines are behind Lagos' rapid rise as a major hub in West Africa? Third, why does Central Africa continue to lag behind the other African regions in airline connectivity? Fourth, how have these changes in Africa's air connectivity impacted the globalization of the continent's cities (Otiso 2010)? Fifth, how have the global airline connections of these 25 African cities changed between 2001 and 2009 and why?

\section{References}

Akpoghomeh, O. (1999) The development of air transportation in Nigeria. Journal of Transport Geography 7: 135-146.

Alderson, A. and J. Beckfield (2004) Power and position in the world city system. American Journal of Sociology 109: 811-851.

Alderson, A., Beckfield, J, Sprague-Jones, J. (2010) Inter-city relations and globalization: The evolution of the global urban hierarchy, 1981-2007. Urban Studies, 47 (9), in press.

Bassens, D., Derudder, B., Witlox, F. (2010) Searching for the Mecca of finance: Islamic financial services and the world city network. Area, 42 (1): 35-46.

Beall, J. and Todes, A. (2004). Gender and integrated area development projects: lessons from Cato Manor, Durban. Cities, 21 (4): 301-310

Beaverstock, J., R. Smith and P. Taylor (2000) World city network: a new metageography? Annals of the Association of American Geographers, 90 (1): 123-134. 
Beavon, K. (1998). 'Johannesburg': Coming to grips with globalization from an abnormal base. In: Fu-chen Lo and Yue-man Yeung (eds). Globalization and the World of Large Cities. Tokyo-New York-Paris: United Nations University Press.

Button, K. (1999) The usefulness of current international air transport statistics. Journal of Transportation and Statistics 2 (1): 71-92.

Castells, M. (1996) The Rise of the Network Society. Oxford, Blackwell.

Cattan, N. (1995). Attractivity and internationalisation of major European cities: The example of air traffic. Urban Studies, 32 (2): 303-312.

Cidell, J. (2006). Air transportation, airports, and the discourses and practices of globalization. Urban Geography, 27 (7): 651-663.

de Blij, H. J. and Muller, P.O. (2008). Geography: Realms, Regions, and Concepts (13th edition). Hoboken, NJ: John Wiley \& Sons.

Derudder, B. (2006) On conceptual confusion in empirical analyses of a transnational urban network. Urban Studies 43 (11): 2027-2046.

Derudder, B. and F. Witlox (2005) An appraisal of the use of airline data in assessing the world city network: a research note on data. Urban Studies 42 (13): 2371-2388.

Derudder, B., L. Devriendt and F. Witlox (2007a) Flying where you don't want to go. An empirical analysis of hubs in the global airline network. Tijdschrift voor Economische en Sociale Geografie 98 (3): 307324.

Derudder, B., L. Devriendt and F. Witlox (2007b) An empirical analysis of the position of major former Soviet Union cities in transnational airline networks. Eurasian Geography and Economics 48 (1): 95110.

Derudder, B., Taylor, P., Ni, P, De Vos, A., Hoyler, M., Hanssens, H., Bassens, D., Huang, J., Witlox, F., Yang, X. (2010) Pathways of growth and decline: connectivity changes in the world city network, 20002008. Urban Studies 47 (9): 1861-1877.

Devriendt, L., B. Derudder and F. Witlox (2008) Cyberplace \& Cyberspace. Two approaches to analyzing digital intercity linkages. Journal of Urban Technology 15 (2): 151-180.

Devriendt, L., G. Burghouwt, B. Derudder, J. De Wit and F. Witlox (2009) Calculating load factors for the transatlantic airline market using supply and demand data - a research note on the identification of gaps in the available airline statistics. Journal of Air Transport Management. 15 (6): 337-343.

el-Khishin, K. (2003) Bidding for "global city" status: a prescription for sustaining Cairo's financial health, Cities, 20 (2): 129-134

Friedmann, J. (1995) “The world city hypothesis," in P.L. Knox and P.J. Taylor (eds) (1995), World Cities in a World-System. Cambridge: Cambridge University Press, pp. 317-331. 
Goetzl, D. (2000) Southwest airlines takes flight fare fight to the web. Advertising Age 71(40): 20-22.

Goldstein, A. (2001) Infrastructure development and regulatory reform in Sub-Saharan Africa: the case of air transport. OECD Development Centre Technical Paper. Paris, OECD no 154: 221-248.

Goldstein, A., N. Pinaud, H. Reisen and X. Chen (2006) The rise of China and India: What's in it for Africa? OECD, Development Centre Studies, Paris (France), May 2006.

Grant, R., and Nijman, J. (2002) Globalization and the corporate geography of cities in the less developed world. Annals of the Association of American Geographers, 92(2), 320-340.

Grant, R. (2009) Globalizing City: The Urban and Economic Transformation of Accra, Ghana. Syracuse, NY: Syracuse University Press.

Hummels, D. (2007) Transport costs and international trade in the second era of globalization. Journal of Economic Perspectives, 21 (3): 131-154.

Kaplinsky, R., D. McCormick and M. Morris (2006) The impact of China on Sub Saharan Africa. Institute of Development Studies, University of Sussex, April 2006. Online available at: http://www.ids.ac.uk/ids/global/AsianDriverpdfs/DFIDAgendaPaper06.pdf

Keeling, D. (1995) Transportation and the world city paradigm. In: P.L. Knox and P.J. Taylor (eds.) World Cities in a World-System. Cambridge: Cambridge University Press: 115-131.

Knox, P. (1996) Globalization and urban change. Urban Geography 17: 115-117.

Lemanski, C. (2007). Global cities in the South: Deepening social and spatial polarisation in Cape Town, Cities, 24 (6): 448-461.

Macario, R. (2008) Low cost airline reaction patterns. Presentation at Air Transport Colloquium 2008: a Laboratory for dynamic developments. December 5, 2008. Antwerp, Belgium.

Malecki, E. J. and Hu, W. (2009) A wired world: The evolving geography of submarine cables and the shift to Asia. Annals of the Association of American Geographers 99 (2): 360-382.

Matsumoto, H. (2004) International urban systems and air passenger and cargo flows: some calculations. Journal of Air Transport Management 10: 241-249.

Miller, W. (1999) Airlines take to the internet. Industry Week 248 (15): 130-134.

Moss, M. (1998) Technology and cities. Cityscape: A Journal of Policy Development and Research 3(3): 107127.

Myers, G. and Owusu, F. (2008) "Cities of Sub-Saharan Africa". In S.D. Brunn, M. Hays-Mitchell, and D.J. Zeigler (Eds.) Cities of the World: World Regional Urban Development, Lanham, MD: Rowman \& Littlefield, pp. 341-383.

Otiso, K. M. (2005) Kenya's Secondary Cities Growth Strategy at a Crossroads: Which Way Forward? GeoJournal 62: 1-2, 117-128. 
Otiso, K. M. and Owusu, G. (2008) Comparative urbanization in Ghana and Kenya in time and space. GeoJournal 71:143-157.

Otiso, K. M. (2010) Book Review of Richard Grant (2009), Globalizing City: The Urban and Economic Transformation of Accra, Ghana, Syracuse: Syracuse University Press, Economic Geography, 86 (1): $111-112$.

Pedersen, P.O. (2001) Freight transport under globalization and its impact on Africa. Journal of Transport Geography, 9 (2): 85-99

Pirie, G. (2006) 'Africanisation' of South Africa's international air links, 1994-2003. Journal of Transport Geography, 14 (1): 3-14.

Pirie, G. (2010) Trajectories of North-South city inter-relations: Johannesburg and Cape Town, 19942007. Urban Studies, 47 (9), in press.

Rakodi, C. (1998) "Globalization trends and sub-Saharan African cities.” In: F.-C. Lo and Y.-M. Yeung (eds). Globalization and the World of Large Cities. Tokyo-New York-Paris: United Nations University Press.

Rimmer, P. (1998) Transport and telecommunications among world cities. In: F.-C. Lo and Y.-M. Yeung, (eds.) Globalization and the World of Large Cities. Tokyo: United Nations University Press: 433-470.

Robinson, J. (2006). Ordinary Cities: Between Modernity and Development. Routledge: London.

SAinfo (June 2009). Advice for Travellers: OR Tambo International Airport, Available online at: http://www.southafrica.info/travel/advice/airports.htm, accessed August 24, 2009.

Sassen, S. (2001) The Global City: New York, London, Tokyo (2nd edition). Princeton: Princeton University Press.

Servant, J.-C. (2005) China's trade Safari in Africa. Le Monde Diplomatique, May 2005. Online available at: http://mondediplo.com/2005/05/11chinafrica

Shatkin, G. (2007). Global cities of the South: Emerging perspectives on growth and inequality. Cities 24 (1): $1-15$.

Short, J., Y. Kim, M. Kuss, and H. Wells (1996) The dirty little secret of word city research. International Journal of Regional and Urban Research 20: 697-717.

Simon, D. (1992). Cities, Capital and Development: African Cities in the World Economy. London: Belhaven Press.

Simon, D. (1995) The world city hypothesis: reflections from the periphery. In: P.L. Knox and P.J. Taylor (eds) World Cities in a World-System. Cambridge: Cambridge University Press, pp. 132-155.

Simon, D. (1997) Urbanization, globalization, and economic crisis in Africa. In: C. Rakodi (Ed.) The Urban Challenge in Africa: Growth and Management of its Large Cities. Tokyo: United Nations University.

Smith D. and M. Timberlake (2002) Hierarchies of dominance among world cities: a network approach. In: S. Sassen, ed., Global Networks, Linked Cities. London: Routledge: 117-141. 
Subramanian, U. and M. Matthijs (2007) Can Sub-Saharan Africa leap into global network trade? World Bank Policy Research Working Paper 4112, January 2007.

Sui, D. Z. (2004). Tobler's first law of geography: A big idea for a small world? Annals of the Association of American Geographers, 94(2): 269-277

Taylor, P. (2001) Specifications of the world city network. Geographical Analysis 33(2): 181-194.

Taylor, P. (2004) World City Network: A Global Urban Analysis. Routledge, London.

Taylor, P., G. Catalano and D. Walker (2002) Measurement of the world city network. Urban Studies 39 (13): 2367-2376.

Yousry, M., Abu-Zekry, T. and Yousry, A. M. (1998) Cairo as a world city: The impact of Cairo's orientation towards globalization. In F.-C. Lo and Y.-M. Yeung (eds). Globalization and the World of Large Cities. Tokyo-New York-Paris: United Nations University Press.

Van der Merwe, I. J. (2004) The global cities of Sub-Sahara Africa: fact or fiction? Urban Forum 15 (1): 3647.

Vespermann, J., A. Wald and R. Gleich (2008) Aviation growth in the Middle East - impacts on incumbent players and potential strategic reactions. Journal of Transport Geography 16(6): 388-394

Zook, M. and S. Brunn (2006) From podes to antipodes: positionalities and global airline geographies. Annals of the Association of American Geographers 96(3): 471-490. 